\title{
MORPHOLOGICAL AND DESCRIPTIVE NOTES ON THE GENUS CRYPTOPLAX.
}

By Henry A. Pilsbry, Sc.D., etc.

Read 9th November, 1900.

(PLATES XIV AND XV.)

The genus Cryptoplax is one of considerable interest to the morphologist, on account of the degeneration of the armour characteristic of the Polyplacophora, and the convergence in outward features to the Aplacophora. If the lack of fossil, or recent, intermediate stages prevents our tracing the descent of the Aplacophora, a parallel process may yet be seen in the Cryptoplacidæ.

The opportunity of describing a new species, very advanced in the degeneration of its valves, has been taken to present certain interesting phases of parallelism between ontogeny and phylogeny among the other species.

In normal Chitons, the contours of the individual valves have been determined largely by purely mechanical factors. The intermediate valves, in close contact with the ones before and behind, are as necessarily arrested from expansion in those directions as a Crepidula plana growing in a narrow shell. Under such circumstances the Crepidula grows long and narrow, and the Chiton valve grows mainly at the sides. The two terminal valves of the Chiton, on their free sides, expand as roundly and naturally as a limpet. ${ }^{1}$ Now in Cryptoplax some of the valves have been freed from the pressure fore and aft, and, as might be expected, they expand freely in length; but the vermiform shape of the animal, and perhaps some of the needs of its little known ways of life, prevent the lateral expansion of the valves for which we should otherwise look. ${ }^{2}$

The general structure of the valves and girdle, apart from the features just mentioned, is not very unlike such Acanthochitidæ as Notoplax, which, in my opinion, is a comparatively primitive member of the family, and consequently nearer the stock whence the Cryptoplacidæ arose.

My studies now show that within the genus there are two widely divergent lines of specialization. In the one, the posterior insertionplate of valve viii projects backward, as in normal Chitons (Pl. XIV,

The posterior sinus in the tail-valve of Mopalia, etc., was mechanically caused by the habit the animal has of raising the median-posterior part of the girdle in order to maintain a free and constant conduit for water from the gills, thus bringing a constant pressure to bear on the growing periphery of the tail-valve in the position of the sinus.

${ }^{2}$ Arthur Adams, I believe, somewhere writes of breaking coral blocks to get the specimens of Cryptoplax, which enter such narrow crevices of the coral that they are stretched out to a foot in length.

VOL. IV.-MARCH, 1901. 
Figs. 8, 9), there is great disparity in the sizes and proportions of the valves, the girdle has a dense covering of blunt spicules, etc. This phylum is represented by $C$. Burrowi and C. Elioti. In the other phylum, the posterior insertion-plate of valve viii is vertical or thrown forward, the tegmentum projecting behind it (Pl. XIV, Figs. 15, 16), the valves are more equal in size and form, and when separated are spaced differently, whilst the girdle spicules are spine-like. C. larvaformis is the most differentiated species of this branch, having assumed senile characters in the stage of maturity, while C. Gunnii is clearly the least specialized, retaining a less aberrant posterior insertion-plate, and less modified sculpture. These relationships may be expressed diagrammatically thus :-

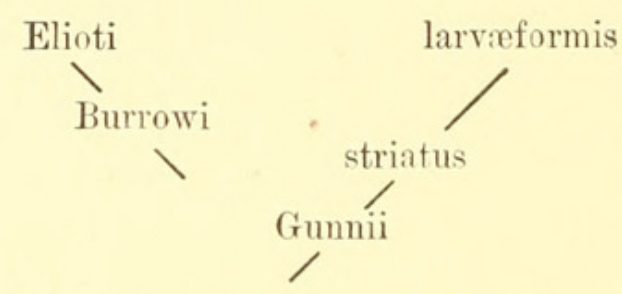

The tropical species are the most specialized, the temperate ones the least.

In the following key the references to proportions or characters of individual valves should be understood to apply to detached valves, not to the portion visible in a perfect specimen. The valves may usually be removed from an alcoholic example without mutilating the girdle or other soft tissues. As each valve is removed it should be numbered, either on the valre itself or, if this be too small, by enclosing each one in a separate vial suitably marked. Neglect of this precaution detracts seriously from the value of the material for exact morphological or systematic work.

\section{Key to the Species of Cryptoplax.}

[N.B. - All references to the proportions or characters of individual valves are taken from the detached valves, and apply to the entire valve, not merely the tegmentum.]

a. Posterior insertion-plate of valve viii projecting backward, the articulamentum projecting behind the tegmentum, the mucro not posterior; pore-tufts obsolete ; posterior valves widely separated, the greatest space between $\mathbf{v}$ and vi.

$b$. Valves i and ii only in contact; iii to viii widely separated, visible through inconsiderable orifices, or punctures, in the integument; the spaces between valves iv to viii very wide.

C. Elioti, n.sp.

$b^{1}$. Valves $\mathrm{i}$ to iii in contact, the next one contiguous; spaces between valves $\mathbf{v}$, vi, and vii very wide; all valves larger than in the preceding species.

C. Burrowi, Smith.

$a^{1}$. Posterior insertion-plate of valve viii vertical, or thrown forward, the tegmentum projecting beyond the articulamentum behind, mucro posterior.

$b$. Valve ii longer than viii, and valves vi, vii, and viii smaller than iv and $\mathbf{v}$; $\mathrm{v}$ to viii having a median sulcus in place of the dorsal area, and widely separated from one another. Spicules of the girdle very short.

C. larreformis, Burr. 
b. Valve viii longer than ii, and valves iv to viii about equal in size and of nearly similar form; a distinct band-like dorsal area developed on valves ii to viii.

c. Anterior three valves surrounded by a fringe of black within one of white spicules; valves $\mathrm{v}$ to viii moderately separated; girdle densely covered with rather long spicules. C. oculatus, Q. \& G.

$c^{1}$. Anterior three valves in contact, the rest more or less widely separated; posterior insertion-plate of valve viii vertical, rather long; girdle sparsely clothed with minute spicules, some larger ones scattered among them.

C. Gunnii, Rve.

$c^{2}$. Valves all in contact or nearly so, slightly wider and less coarsely sculptured than in $C$. Gunnii; posterior insertion-plate of valve viii short and thrown forward; girdle densely clothed with long spicules.

C. striatus, Lam.

\section{Cryptoplax Elioti, n.sp. Pl. XIV, Figs. 1-11.}

Sub-cylindrical and vermiform, widest behind, gradually tapering anteriorly; pale buff-grey, with small and very sparsely scattered red, or brick-red maculæ, more profuse on the under side of the girdle; densely clothed with short, flattened spicules, which give the surface a silvery gleam like some of the Aplacophora. Valves i and ii exposed and contiguous; iii and iv almost concealed, sunk in a groove; the next three very widely separated, also greatly reduced, but visible through small round orifices; valve viii minute and oblong.

Anterior valve small, truncated-oblong, the tegmentum longer than wide, eroded and sparsely punctate; the articulamentum white, more than double the length and breadth of the tegmentum, the posterior angles produced backward, anterior margin having three notches; muscle-scars deep. Valve ii with the tegmentum touching that of valve i, lozenge-shaped, tapering fore and back, faintly rugose; articulamentum sub-triangular, wide in front, narrower and bilobed behind. Valve iii much smaller, separated from the preceding, broadly sagillate, with small narrowly piriform tegmentum. Valve iv similar to iii, but still smaller, rather widely separated from it; both of them being sunk in a groove and concealed by the surface spicules, though not enclosed in the integument. Valve $\mathrm{v}$ separated from the preceding by nearly one-fifth the total length of the animal, very minute, similar to valve iv hut shorter, the tegmentum oblong, with distinctly raised dorsal area and slightly rugose latero-pleural tracts. Valve vi still more widely separated from the preceding, and similar to it. Valve vii somewhat less widely separated from vi, larger and squarish, the tegmentum with a few longitudinal striæ at the sides. Valve viii oblong, truncate, and emarginate in front, rounded behind, the articulamentum projecting beyond the tegmentum on all sides, insertion-plate projecting laterally and backward; sinus small and shallow; the tegmentum narrowly oblong, rounded behind, acuminate in front, the mucro nearly posterior; dorsal area smooth except for some transverse wrinkles, tapering in front, latero-pleural tracts sculptured longitudinally with a few coarse striæ, somewhat granose posteriorly.

Girdle densely clothed with oblong scales, which have a silvery gleam, are blunt at their free ends, and have one or two longitudinal 
keels and often some striæ (Pl. XIV, Fig. 11). There are no discernible pores or pore-tufts and no marginal fringe. The lower surface covered with far shorter, smaller scales than the upper.

Foot wholly concealed in the ventral groove (in alcoholic examples), narrow, but with flat sole and crenate edges. Gill row rather less than one-fifth the total length of the animal.

Length (of an alcoholic example) 55 to $60 \mathrm{~mm}$.

Hab.-Apia, Samoan Islands, collected in 1899 by Sir Charles Eliot, H.M. Commissioner to Samoa, after whom the species is named. Type No. 77,308: Conch. Coll. Acad. Nat. Sci. Philadelphia.

This is the most divergent of all the known species of Cryptoplax, the valves being more reduced in size and more widely separated than in any other. The bright spicules give the animal a silvery gleam, like Chatoderma. Apparently the Cryptoplacidæ are developing a stock parallel to the Aplacophora in their vermiform shape, loss of valves as protective armour, and renewed predominance of spicules for this purpose, and the posterior position of the gills.

The dimensions in millimetres of the individual valves of the type are as follows :-

\begin{tabular}{|c|c|c|c|c|c|c|c|c|c|c|}
\hline & & \multicolumn{2}{|c|}{ Valve i } & ii & iii & iv & $\mathrm{v}$ & vi & vii & riii \\
\hline Length & $\ldots$ & $\ldots$ & $3 \cdot 2$ & $4(?)$ & $2 \cdot 4$ & $1 \cdot 8$ & $1 \cdot 3$ & $1 \cdot 3$ & $1 \cdot 8$ & $2 \cdot 8$ \\
\hline Breadth & $\ldots$ & $\ldots$ & $2 \cdot 8$ & $3 \cdot 1$ & $2 \cdot 1$ & $1 \cdot 6$ & $1 \cdot 1$ & $1 \cdot 0$ & $1 \cdot 3$ & 1.5 \\
\hline $\begin{array}{l}\text { TEGM } \\
\text { Length }\end{array}$ & NTUM & & 1.9 & $2 \cdot 9$ & $1 \cdot \tilde{0}$ & 1.1 & $1 \cdot 1$ & 1.2 & 1.6 & $\cdot 1$ \\
\hline Breadth & $\begin{array}{l}\cdots \\
\ldots\end{array}$ & $\begin{array}{l}\cdots \\
\ldots\end{array}$ & $1 \cdot 6$ & $1 \cdot 5$ & 0.6 & 0.5 & 0.6 & 0.6 & 0.7 & 0.4 \\
\hline
\end{tabular}

It will be noted that the articulamentum is smallest in valves $\mathrm{v}$ and vi, but the tegmentum in valves iii and iv. In $C$. larvaformis the two layers of the valve decrease together, and are smallest in valve vi. In the latter species there is no conspicuous change in the form of the sutural laminæ between valves iii and viii, but in C. Elioti these laminæ become abruptly short at valve v, continuing so upon the subsequent valves. In the valves anterior to $\mathrm{v}$, the insertion-plates and sutural laminæ are formed more as in all the valves of $C$. larvaformis. The shortening of the articulamentum of valves v-viii in C. Elioti indicates accelerated degeneration of the valves in the posterior half of the body.

The nearest ally of this species is C. Burrowi of E. A. Smith, which has a posterior valve of the same shape, but its valves are far less degenerate.

\section{Cryptoplax larvefformis (Burrow). Pl. XiV, Figs. 12-16.}

The girdle in this species resembles that of $C$. Gunnii more than that of any other. The valves of adults show distinctly senile features, and the ontogeny has evidently been considerably ' accelerated.'

In a young specimen (length in alcohol $35 \mathrm{~mm}$.), valves ii to viii show a well-defined dorsal area as a smooth median band; on either side of this are numerous riblets parallel with it. This condition obtains until the tegmentum of valve viii is nearly $3 \mathrm{~mm}$. long. In 
equally young $C$. striatus we find a similar sculpture, except that the riblets are more beaded. When the tegmentum has attained the size just indicated, an abrupt change supervenes; the lateral riblets become more or less undulating, and converge forwards, meeting at the ridge, where the defined dorsal tract of the preceding stage has now disappeared. This sculpture lasts until a length of about $45 \mathrm{~mm}$. is attained by the tegmentum of valve viii (which I am simply using as a standard, the stages varying somewhat with the valve, and slowest, or lagging in front). Then another abrupt change appears, the dorsal tract being replaced on the median and posterior valves by a median sulcus, and the lateral riblets by irregular wrinkles parallel with the lateral margins of the tegmentum. These stages are shown in Figs. 12, 13, and 14 of Pl. XIV. Fig. 12 shows the first and second stages, up to the beginning of the third, the total length of the tegmentum in the valve figured being $4.5 \mathrm{~mm}$. Fig. 13 represents valve vii of an older specimen, in which the anterior half of the tegmentum has assumed the sculpture of the adult. Fig. 14 shows the adult valve, in which the early stages in the development of the sculpture have been removed by erosion. Length of tegmentum $8.5 \mathrm{~mm}$.

Or to tabulate the stages, using Hyatt's nomenclature :-

Statie.

Infancy, or nepionic. Youth, or neanic.

Maturity, or ephebic.
VALVE-SCULPTURE.

Dorsal area distinct; latero-pleural tracts with parallel riblets. Dorsal area disappearing; latero-pleural tracts with waved or irregular riblets.

A dorsal sulcus; latero-pleural tracts with converging rugæ parallel to the lateral margins.

Now the stage of maturity in C. larvaformis corresponds with the gerontic or senile stage in $C$. striatus; old specimens of that species (Pl. XV, Figs. 20, 23) showing one or two lateral rugæ replacing the longitudinally radial, irregular wrinkles of the merely mature valve. In other words, what is a senile characteristic in $C$. striatus has become a characteristic of the next earlier stage in C. larvaformis. ${ }^{1}$

The irregular rugæ of mature $C$. striatus answer to the irregularly waved wrinkles of the neanic C. larvaformis. If the latter species ever had a distinctly granose-ribbed stage, like the earlier stage of C. striatus, it will be shown by younger specimens than mine, or it has been lost.

It appears probable, from the study of young Cryptoplax, that the sculpture in that genus was primarily that of the less modified Acanthochitidæ, such as Acanthochites (Notoplax) Matthewsi, in which the sculpture consists of longitudinal riblets, granose near the beaks.

Returning to $C$. larvaformis, it may be noted that the valves decrease gradually in width from the first to the fifth, which is narrowest; then there is a slight increase to the seventh, the

1 In Chitons generally the senile stage is characterized by crowded rugæ parallel to the lateral margins of the valves, and partial or complete effacement of other sculpture there, erosion of the valves being an incidental feature attending age. 
terminal one being a little narrower; and the exposed portions of valves $\mathrm{v}$ to viii are smaller than that of valve iii. In $C$. Gunnii and $C$. striatus, valves iii to viii are of about equal width, and the tegmentum does not vary noticeably in size or shape from the fourth to the eighth valves.

C. larveformis was taken by Mr. Eliot at Apia, Samoan Is., a locality not hitherto recorded for the species.

\section{Cryptoplax Gunnit (Reeve). Pl. XV, Figs. 17-19, 24-26.}

This form was considered a variety of $C$. striatus by Mr. Smith, ${ }^{1}$ an opinion in which I formerly acquiesced. The study of numerous well-preserved alcoholic specimens received from Mr. Bednall, however, now convinces me that $C$. Gunnii is entitled to specific rank. Compared with $C$. striatus, the valves are decidedly narrower and more coarsely sculptured; the mucro of valve viii is less posterior ; the posterior insertion-plate is rertical, with only a very slight upward wave or sinus behind, and the whole cavity of valve viii is visible when viewed directly from below. In $C$. striatus (Pl. XV, Figs. 20-23) the valves are wider and more finely sculptured, the mucro of valve viii is produced backward in adults, the posterior insertion-plate slopes forward, is shorter and has a distinct sinus behind, and viewed from below, conceals the posterior end of the valve-cavity, until in quite old individuals this is filled up

The valves in $C$. Gunnii are also far more widely separated, valves i to iii only being in contact; valve iv is but shortly removed, the others quite widely separated, the greatest space lying between valves $\mathrm{v}$ and vi; vi and vii being nearly as widely separated.

The body is more vermiform, less broadly flattened beneath, and less depressed. In individuals with valves of the same size, the body of $C$. Gunnii is half as long again as that of $C$. striatus; and the integument bears wholly different spicular armature.

C. striatus bristles with a dense covering of short, stiff, acicular spicules, directed slightly forward, with an under-coat of shorter spicules, ${ }^{2}$ while in $C$. Gunnii there is a rather scant clothing of minute, very short, stout, pointed spicules, with larger ones sparsely scattered among them (Pl. XV, Fig. 25, $\times 30$ ), or wanting. The spicules are reddish-brown in places, elsewhere white, thus producing the marbled colour-pattern of the animal.

The young of $C$. Gunnii differs from the adult in the approximation of all the valves, and in retaining more of the longer, white spicules, sparsely scattered over the surface (Pl. XV, Fig. 24, $\times 30)$. Both of these characters point to ancestors with more the organization of the genus Choneplax. The form of the tail valve does not differ from that of the adult.

1 Zool. Coll. H.M.S. “ Alert," p. 85.

2 See Manual of Conchology, vol. xv, pl. xi, fig. 37 . 


\section{$2 \mathrm{BHL}$ Biodiversity Heritage Library}

Pilsbry, Henry Augustus. 1901. "MORPHOLOGICAL AND DESCRIPTIVE NOTES ON THE GENUS CRYPTOPLAX." Proceedings of the Malacological Society of London 4, 151-157.

View This Item Online: https://www.biodiversitylibrary.org/item/53747

Permalink: https://www.biodiversitylibrary.org/partpdf/202767

\section{Holding Institution}

Smithsonian Libraries

\section{Sponsored by}

Smithsonian

\section{Copyright \& Reuse}

Copyright Status: Public domain. The BHL considers that this work is no longer under copyright protection.

This document was created from content at the Biodiversity Heritage Library, the world's largest open access digital library for biodiversity literature and archives. Visit BHL at https://www.biodiversitylibrary.org. 